The Geneva Papers on Risk and Insurance, 23 (No. 88, July 1998), 331-355

\title{
Insurance and the Euro
}

\author{
by Michel Albert* and Patrick Lefas**
}

When the Heads of State and Governement decided in Maastricht to create a single currency at the latest date of January 1, 1999, they had in mind the objective encapsulated in the Rome Treaty to lay the foundations of an ever closer Union among the people of Europe. Becoming a European Union, the Community favoured the longevity and the development of its own potentiality. One cannot fall in love with a single currency. Yes, indeed, but the determination that the national governments, with a large support of their fellow citizens, have shown to pursue the ideals of the founding fathers of Europe seems to give continuously a clear evidence of a "Living Community". It is not extraordinary, in that context, to see the emergence of a similar philosophy within the business community. The concepts of "Living Company" enshrined in Arie de Geus'book" ${ }^{1}$ or of "Stakeholder Society" developed in the anglo-american economic literature tend to answer the same requirements of ethical principles.

As far as the Euro project is concerned, the European insurance industry expressed very early a strong feeling in favour of a European single currency, even at a time when few financial operators were convinced it would come according to the Maastricht Treaty. In an article published in a french financial periodical, "Revue d'économie financière" (fall 1992), Denis Kessler and Pierre Bollon considered that the establishment of the Economic and Monetary Union ought to lead to a period of monetary stability very beneficial to insurance mechanisms. But in fact, as the eight delivery of the periodical Risques (December 1991) testified, every attention was paid at that time to the negotiation of the third directives and to their potential consequences, and the role of the single currency was not really considered.

\footnotetext{
* Member of the Monetary Policy Council, Banque de France, Paris.

** Director for European and International Affairs, FFSA (Fédération Française des Sociétés d'Assurances).

${ }^{1}$ See Societal - No. 13 - November 1997 - Article by Michel Albert: The Living Company.
} 
Three years ago, at the general assembly of the Geneva Association in Bordeaux, the leaders of the European industry strengthened their endorsement regarding the respect for the timetable of the single currency and for the convergence criteria. Last december, the Geneva Association published interesting contributions from Prof. Gerry Dickinson, Dr Klaus-Wilhem Knauth, Frank Thomas, Filomeno Mira, Joao Ramalho Talone and from the President of the Reinsurance American Association (RAA), Frank W. Nutter, who consistently share the same views regarding the impact of the Euro on insurance companies and insurance business.

Three main arguments are now commonly accepted:

1) EMU means a shield against inflation and exchange risks which is the best protection for savings.

The development of the life market in France since the mid-eighties has clearly shown the impact of a stable environment. For the last twenty years, the growth rate of mathematical reserves, which have their counterpart on the investment side, has reached $18 \%$ per year (see chart 1 below).

Figure 1: Investment deposits of French insurance companies

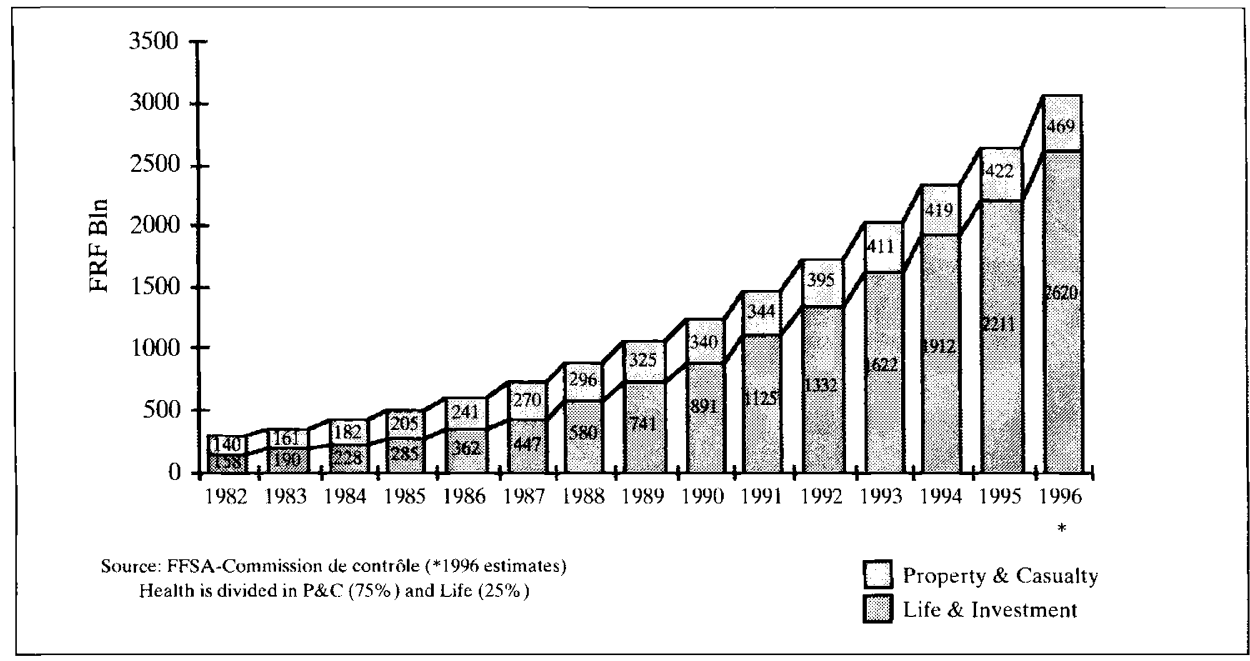

2) The second argument is that the convergence criteria require an adaptation of the Welfare State to reduce public deficits, and accordingly open new opportunities for business in health-care insurance, occupational pension schemes or dependency benefits.

One may refer to the privatization of health-care in the Netherlands, or Prime Minister Prodi reforms regarding the public pension schemes. In this regard, France lags behind the other Member states with some kind of myopia on the structural imbalances of public and interprofessional PAYG schemes. As the European Commission has recalled in its Green Paper on the supplementarty pension schemes in Europe, several Member States (Spain, Finland, France, Germany, Italy, Luxembourg and Netherlands) might reach in 2030 without further reforms a ratio of pension expenditures to GDP between $15 \%$ and 
$20 \%$. The vast majority of the benefits continue to come from the first pillar: $88.8 \%$ of total pension pay-out in 1994 for the EU 12 (Finland, Austria and Sweden excluded), against $7 \%$, from the second pillar, $0.9 \%$ for the third pillar and $3.3 \%$ corresponding with social public care. The importance of pension funds expressed as a percentage of GDP is vastly different from one country to the other (see Table 1).

Table 1: Total Pension Fund Assets as a Percentage of GDP at End 1993

\begin{tabular}{|l|c|c|c|}
\cline { 2 - 4 } \multicolumn{1}{c|}{} & $\begin{array}{c}\text { GDP } \\
\text { billion } \$\end{array}$ & $\begin{array}{c}\text { PF Assets } \\
\text { billion } \$\end{array}$ & $\begin{array}{c}\text { PF Assets } \\
\text { in\% of GDP }\end{array}$ \\
\hline Belgium & 201.24 & 6.89 & 3.42 \\
\hline Denmark & 129.13 & 25.98 & 20.12 \\
\hline France & 1194.69 & 41.10 & 3.44 \\
\hline Germany & 1824.02 & 105.95 & 5.81 \\
\hline Ireland & 45.17 & 18.14 & 40.16 \\
\hline Italy & 947.28 & 11.65 & 1.23 \\
\hline The Netherlands & 295.15 & 261.30 & 88.53 \\
\hline Spain & 456.59 & 10.08 & 2.21 \\
\hline Switzerland & 233.96 & 185.90 & 79.46 \\
\hline UK & 903.12 & 717.25 & 79.42 \\
\hline US & 6000.31 & 3546.00 & 59.10 \\
\hline Japan & 4025.47 & 1800.00 & 44.72 \\
\hline
\end{tabular}

Source for PF assets: EFRP - EU Committee, for GDP: Eurostat

3) The third main argument in favor of the single currency is that EMU creates the possibility to achieve economies of scale that the single market up to now has failed to bring.

It will allow a better allocation of insurers' resources through development of crossborder transactions, centralised assets and cash management or optimised asset/liability management techniques. The rationale behind this last argument is that Insurance remains a highly regulated services industry for reasons of consumers protection, that has impeded economies of scale. The third Community directives have certainly represented a major breakthrough in the creation of a single insurance market with harmonisation of licensing and oversight procedures and with the freedom of premiums' calculation. Additional progress is expected with the single currency, even if the possibility of selling the same product all over the European Union is not yet within reach.

The European insurance industry has always been very oriented toward international markets, even before the second World War. But it has always underwritten premiums in local markets through branches and subsidiaries, because of pronounced differences in the regulatory framework as well as in the tax regimes and in the national contract laws. In France, for instance, the volume of premium income through the freedom of services only represented in 1996 FR 460 million, with a reference to an amount of domestic premium income of FR 700 billion. 
The official completion of the single market has not changed the insurance business. It has not brought about either a standardization of the products or a homogeneousness of the distribution channels. A movement of mergers and acquisitions, which the french insurance companies actively participated in, forestalled the adoption of the third directives. But with more than 4800 existing mutual and stock companies, the European insurance industry is not highly concentrated if one compares it with the industrial sector (car manufacturers, electric power, oil industry...). The single market up to now has failed to change the main features of the insurance industry. The Euro should do it.

\section{The Tidy Preparation of the Insurance Companies to the Changeover to the Euro}

The changeover to the Euro is structured round three key dates which are now very well known from the insurance companies, their personal and their distribution networks.

On January 1, 1999 the Euro will become the single currency of all participating Member States, the national currencies being no longer than non decimal territorial subdivisions. The capital markets will switch to the Euro over the week-end so that when they reopen on January 4, all the listed values, all the negotiations and transactions, all the clearing and settlement procedures will be made in Euro.

The national changeover programmes (see table 2) and the money market outlines have described the detailed conditions of the changeover for every market and the preparatory tasks to be handled in coordination among all the capital market players. In most of the countries, the insurance industry has been closely associated to task forces and working parties coordinated by the Central Bank, banking associations and confederations of business industries put in place to prepare recommendations for their government. It has paid a lot of attention to the rating policy of banks as well as to the industrial organisation of the switchover of capital markets to the Euro which may have an impact on its asset management activity and on its own competitiveness. It has been influential as from the beginning of the transition period, to get from the banks, an offer of scriptural payments in Euro and from the government, the right to fill its tax inconse statement in Euro, if the company has switched over to the Euro its accounts and information systems and the dual display of tax and social ceilings and thresholds.

The European Commission has played a major role in circulating information among the national officials, to create an emulation in the search for adequate translation of the principle "no obligation no legal prohibition", to lift the uncertainties regarding the legal continuity of contracts and indexes thanks to adequate working of the two Community Regulations.

In most of Member States, it has been decided to proceed, at the inception of the third stage of the EMU, to convert into Euro a significant part of the national public debt outstanding (more than seventy per cent of the outstanding amount in twelve out of 14 Member States). Only two Member States, Austria and Finland, which hold an important part of their public debt in foreign currencies will limit the redenomination of public debt to a minimum ( $26 \%$ of the Treasury bonds consisting of the most liquid lines in Austria). The size of the conversion will be still more marked as far as the negotiable public bonds debt is concerned. Ten countries will make a comprehensive changeover, out of which seven are expected to be participating Member States. The positions of different countries 
are less uniform regarding the money market. In Austria, only $50 \%$ of the money market will be converted. In Portugal, no decision is taken yet. In Germany, the "bubills" market, which is not yet very developed (around DEM 20 bn), will not be converted. The position is similar in the United Kingdom. On the contrary, France and to a lesser extent Belgium, Spain and Italy have decided to proceed very systematically to convert all the outstanding public debt, including the monetary notes close to the maturity date.

The method of redenomination differs for technical reasons from one country to the other. France and the Netherlands have chosen a conversion method ("bottom up approach") which includes redenomination on the basis of fixed minimum denomination of one Euro bonds with cash compensatory payments ${ }^{2}$. The other countries will apply a simple redenomination which consists of creating nominal amounts to exact numbers of eurocents.

On January 1, 2002, the Euro bank notes and coins will be introduced and the national currencies notes and coins will be progressively withdrawn from the market until July 1 , 2002 at the latest date. But the dominant position in Europe is that the period has to be the shortest one possible. All the legal instruments denominated into national currency will move automatically to a Euro reference. All the transactions with the clients will be made in Euro. The difficulty of this period of time greatly depends on the magnitude of the last minute migration of the economic agents to the Euro.

Between these two dates, the insurance companies, like every other company, will have to accommodate their business and their book-keeping information systems to the principle "no obligation-no prohibition".

All the aspects of the insurance activity will be affected. It explains why in all the participating Member States an intensive preparatory work was launched two years ago and in most markets the national insurance trade-associations have coordinated the work and have published handbooks. It is interesting to notice that the basic choices differ significantly from one market to the other regarding the offer of new contracts in Euro or the changeover of existing contracts to the Euro.

With competition from its networks (general agents, salaried sales forces, agencies, etc.) and from their professional partners (brokers), and based upon reactions from their customers and prospects, it is for every insurance company to organize and implement the procedures and tools that will enable it, according to its needs and objectives, to propose or accept contracts denominated in Euro when the transition period begins. Opinion polls have not clearly identified until now a real demand for Euro denominated insurance contracts. In the commercial lines, the positions expressed by medium and small size companies are not stabilized because they have started, only a few months ago, reflecting upon their own choices. From the opinion polls or consumer reactions through Internet or follows:

2 The conversion rate will apply to the minimal outstanding of interested lines of business as

number of securities $x$ nominal value in national currency of the bond

conversion $\mathrm{x}$ nominal value in one Euro bond

Therefore, this method takes as a starting point individual holdings, redenominated in one Euro bonds and cashing out for the decimals. 
over the green phone lines, it appears doubts on the legal continuity of the contracts and questions regarding the possibility to break off contracts as soon as the Euro becomes the official currency. Communication programmes will have to focus on these concerns.

The CEA has played a role of coordination of national positions on issues of common interest, and has been instrumental in circulating information on the problems raised and solutions considered in every market.

From a French perspective, the series of studies and contracts carried out during the preparation of the handbook led to the following findings:

1) It seems quite likely that a market demand for contracts in Euro will emerge as soon as the transition period begins, particularly in life and investment business, at least for individual contracts, and in property business, involving large business risks for international groups and export companies.

2) It also appears quite likely that commercial pressure from customers making orders could lead to a gradual shift to the Euro by many suppliers and subcontractors.

3) Moreover, competition in France and abroad will intensify, particularly in household savings management. This clearly creates a strong argument to establish a supply of products in Euro.

4) In the context of the health and welfare lines, where pressure from foreign competition is not very noticeable, the studies have shown that the transition to the Euro would be heavily influenced by the decisions of public administrations and compulsory social security programmes.

5) Marine, Aviation and Transport, which is already extensively internationalized, will have to adapt to changes in practices of international customers in the choice of transaction currency.

6) For the reinsurance lines, ceding companies and reinsurers, familiar with the multicurrency management of their contracts, have sought mechanisms for simplifying the transition to the Euro, while still preserving the transparency of information on past and future contract developments.

Consequently, the profession has recommended that, when the transition period begins, companies will be able to meet the demands of Euro-denominated contracts emanating from the market and to accept to the greatest extent possible, at least for property business, the demands that existing contracts denominated in French francs be changed to, or at least managed in Euros. Companies should also be prepared to meet the spontaneous demand that could arise to have a Euro version available for at least one contract per principal insurance line. Beyond that, they are, of course, free to move at their own pace.

All the reflections and preparatory works have been conducted with the threefold concern of coming up with solutions that combine:

- reactivity to changes in demand;

- simplicity of management procedures, and

- a quest for the lowest cost to the customer and the company. 
Within the last few months, the debate has been focused on banking and conversion charges arising from the introduction of the Euro and on the dual display issue. All the insurance companies have considered that there is no objective reason to impose fees when changing from one monetary expression to the other within the country during the three years of the transition period. At cross-border trade level, there still will be monetary handling which may justify fees, but the "handling commission" should be appreciably lower than the present cost of such transactions. European insurers strongly support the decision already taken by Austrian, Belgian and German banks to apply this scheme in their respective countries.

The Round table on the practical aspects of the Euro organized by the European Commission in Brussels on 26, February 1998 has brought up some good news regarding the commitments of the European banking industry. According to a letter sent by the European Banking Federation to Commissioner Monti, two commitments have been taken:

- Banking operations in Euro will not be priced differently from the same operation in domestic currency;

- The bulk of scriptural operations between the Euro and a domestic currency during the period where both exist will be free of charge, except in those cases where they require a substantial service on the part of the bank.

But some uncertainties remain regarding the consequences of the new rating policy of the banks, including cross-border payments and bank cheques, which are of great importance for the competitiveness of the insurance companies.

Dual display will also be instrumental in facilitating the switch over to the Euro for all economic actors involved. Given the diversity of pricing systems currently in use including in insurance, the European Commission has recognized it is imperative that there be flexibility in the approach to dual displays, with the view to keeping the costs to a minimum and to providing clarity and certainty to citizens. Therefore, it has recommended the working-out, sector by sector, of codes of good practices. In this regard, the FFSA has just adopted, as a follow-up to its 1997 handbook or "Vade-mecum Euro", recommendations for its members on the key informations along the life of different kinds of contract which may be usefully and easily expressed on a dual display basis.

Similar principles will apply in most of the Euro area Member States, either under guidelines from the national associations or at the initiative of companies themselves.

The preparatory work is under fast progress in the insurance industry on every aspect of the process, including the capital markets and the change over of information systems to the Euro. It is consistent with the prevailing conviction that the third stage of the EMU will offer major opportunities for growth, innovation and improvement of financial results.

\section{The Asset Management Revolution}

The Euro will mark a substantial change for European bond markets in terms of size and liquidity, credit aspects and benchmark choice, for derivatives and to a lesser extent for equity markets. Investors, in the first place insurance companies, will face a challenge in adapting to this new world. 
By removing the volatile exchange risk component of intra-EMU cross-border financing costs, the introduction of the Euro has the potential, in absolute terms and compared with any reasonable benchmark, for creating the largest domestic financial market in the world. At end-1995, according to IMF analysis, the market value of bonds, equities and bank assets issued in EU countries amounted to more than \$27 trillion, roughly the same order of magnitude as World GDP (94 percent). If the Union includes 11 Member States, as it is now recommended by the European Commission and expected from the European Summit on May 2, it would roughly equal the size of the U.S. domestic market.

The comparison with the US capital market (see table 3) deserves careful thought, because it may foreshadow the functioning of a capital market in a monetary Union. Three existing differences may fade with time.

1. US bank assets account for only 22 percent of the total assets outstanding against a figure of 54 percent in the Euro-11. EU private entities ought to finance their activities more and more through bond and equity financing, for obvious reasons of return on equity, even if the bank loan conditions within the major markets have never been as low as they are now. For each dollar of bank borrowing according to the IMF data ${ }^{3}$, European private firms borrowed in 1995, on average, only 50 cents through private securities issues against more than two dollars for US firms. It gives an indication of the moving forward margin.

2. The breakdown of bonds by category of issues (public bonds, financial institutions, corporate bonds) is quite different in Europe and in the US. Treasury bonds are dominant in continental Europe, but most of this public debt is born by domestic institutional investors, notably insurance companies. The $3 \%$ budgetary deficit ceiling and the leverage of the Stability Pact will create conditions for an expansion of corporate bonds market. The progression margin seems to be quite significant, since of end-1994 bonds accounted for 5.7 percent of the total liabilities of non financial firms in France, and less than 1 percent in Germany, while they accounted for 18.8 percent of the total liabilities of U.S. non financial firms.

The commercial paper market should also enjoy a good development in Europe, because the conditions will be more attractive than bank financing, and its share in the bonds outstanding will grow. It will be interesting to see the differences of behavior among the national capital markets of the Euro area. Will the German model with its heavy reliance on bank financing resist?

3. The last difference lies in the assessment of credit risk. Thanks to the matching rule principle that the insurance companies have to comply with, the national issuers have benefited until now from attractive conditions and have not had really to compete with foreign issuers. The spread wideness is about three times more extended on the U.S. capital market. The conditions will change dramatically with the arrival of the Euro. A keen attention will have to be paid to the quality of signature of the issuer. Junk bonds or upgrading securitization techniques will appear on the market. Securities pricing will

${ }^{3}$ Source: IMF-International capital markets - November 1997. 
depend on the relative value of underlying credits rather than judgments on macroeconomic fundamentals of currency values. But issuing techniques, clearing and settlement procedures, and legal procedures will have an influence on the cost of raising funds.

Therefore, we can assert that the Euro will actually be instrumental in encouraging further securitization of European finance, greater uniformity in market practices, more transparency of pricing and increased market integration, all of these elements being of crucial importance for the insurance companies in their financial activity, since they work towards increasing the depth and liquidity of European securities markets and breaking down market segments within Europe.

More precisely, major changes on the Bond, Equity and Derivatives Markets will occur.

Before examining these various changes, we can notice that the development of an EMU repo market, with collateralized borrowing and lending, will enable insurance companies to improve their cash position.

\section{A. The bond market}

The Euro bond market will certainly be large, but as a starting point it will not be homogeneous. The composition of each national market differs with a wide variety of instruments (Pfandbriefe in Germany, CTES in Italy, etc....). With regard to government debt, issuing procedures, methods of dealership, maturity structure, size of benchmark issues greatly differ from one country to the other. The segmentation of the market gives an advantage to the domestic investors but also to the domestic issuers. The movement toward harmonization and homogeneousness will come from the market forces as well as from Government initiatives or from community directives.

- As far as the government bond market is concerned, the introduction of the Euro will reduce the cost of issuing and investing in government securities and will provide a strong incentive for the harmonisation of market practices (e.g. auctioning techniques, issue calendars, maturity spectrums) toward the most transparent and cost effective practices for both issuers and investors. The European insurance industry has encouraged a European-coordinated standard for the bond markets (market agreements, primary market) and in the medium term a European coordinated index.

A number of discussions have been held among the professionals and the Central Banks. Some progress has been made for the last few months about the market conventions. It has been notably agreed to use the Actual/Actual day-counts for interest accrual on bonds. On the contrary, no progress has been registered for the question of coupon frequency which greatly depends on the issuers vision. Most EU bond markets have annual coupons, but the British, Italian, American and Japanese government bond markets have semi-annual coupons. Some bonds are quoted in decimal prices (100.50), or in terms of yield $(6.38 \%)$, with others shown in fraction practices $(11612 / 32)$. The institutional investors consider that an harmonisation of coupon frequency for bonds issued in Euro is desirable. 


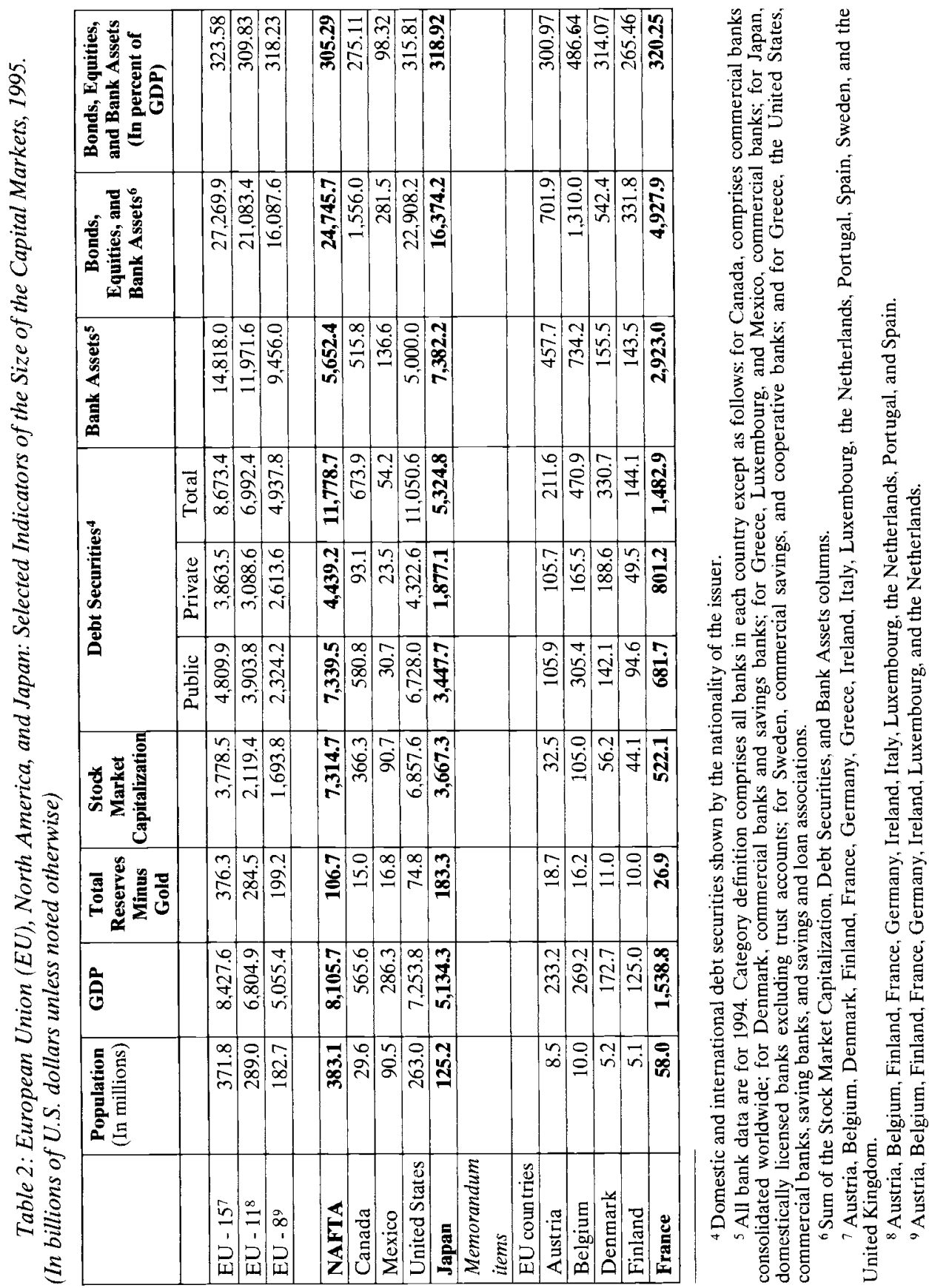



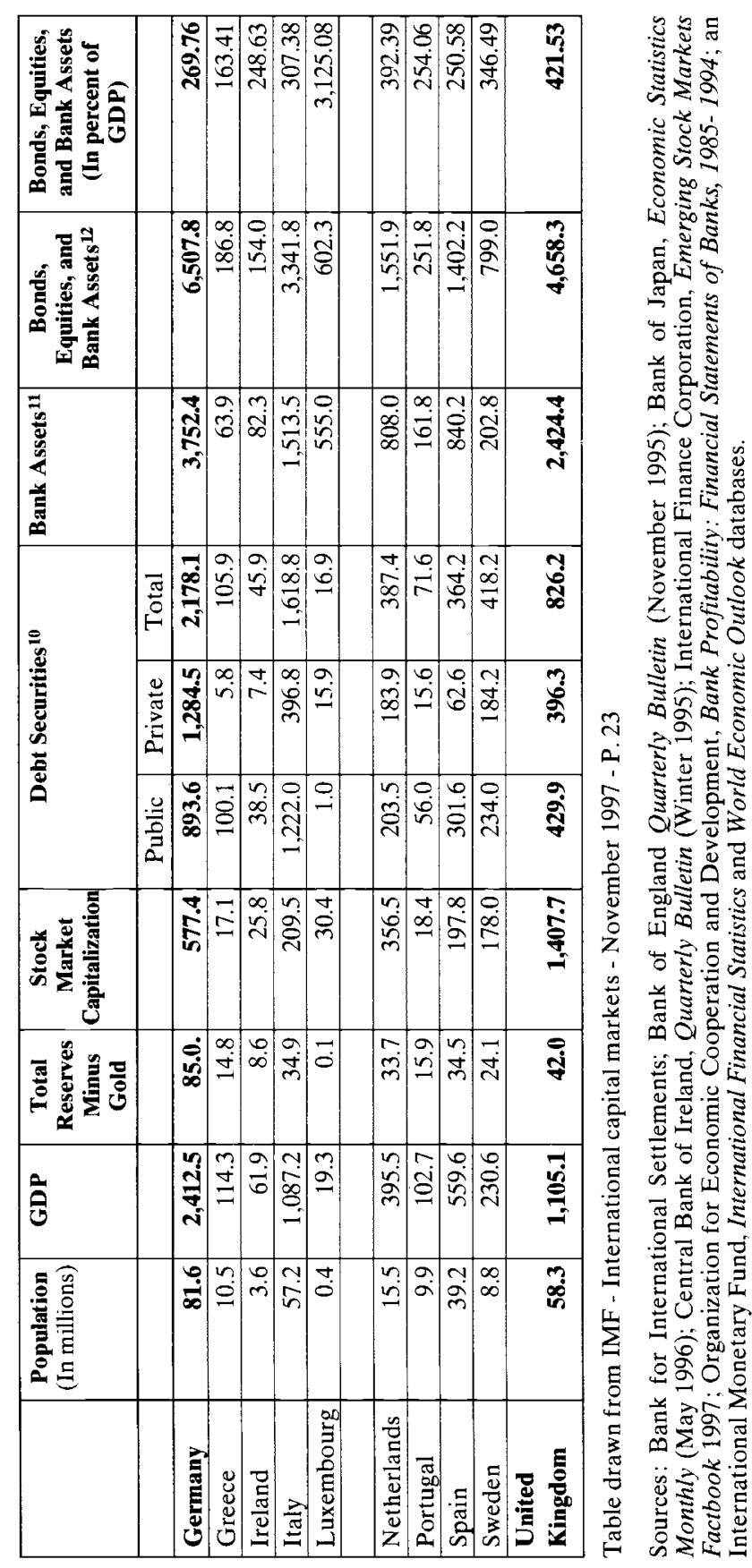

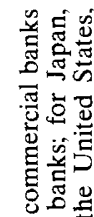

s. 즌

言

这

通可

象金

을.

a

둥 :

겅정

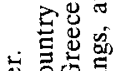

它

氮㝴

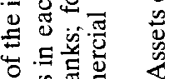

氙栲

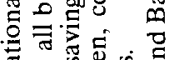

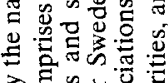

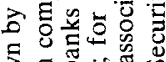

है 5 is

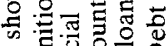

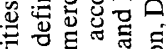

들

이요.

5 过 on

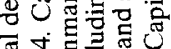

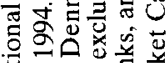

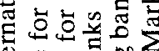

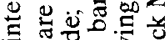

吸定

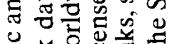

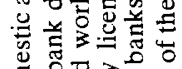

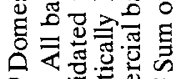

$\subseteq=$ :

ᄀ 
Beyond the desire of harmonisation of market practices, as IMF picked out, it is reasonable to expect market segmentation to diminish. The refocus on credit risk by both issuers and investors is likely to increase cross-border competition between financial intermediaries for bringing new issues to market and for allocating investment funds accross the Euro area. The pricing of credit risks will start with the outcome of spreads convergence or more precisely squeezing in the preparatory process to the Euro, as it appears in table 4. This evolution anyway was general in the world until the explosion of the financial crisis in Asia.

Table 4: Spreads of EU Sovereigns for ten year Bonds with the German Bund as a reference

\begin{tabular}{|l|c|c|c|c|c|}
\hline & France & Netherlands & Belgium & Austria & Finland \\
\hline $\begin{array}{l}\text { less than 10 } \\
\text { basis points }\end{array}$ & +2 & -4 & +9 & +10 & +9 \\
\hline $\begin{array}{l}\text { between } 10 \\
\text { and 30 basis } \\
\text { points }\end{array}$ & +19 & Ireland & Italy & Portugal & Ecu \\
\hline
\end{tabular}

Reference: FFSA February 14, 1998 - Les Echos

Therefore, it is reasonable to expect that credit spreads between EMU member country issuers would be more or less within the same range as that of triple A-rated corporate issues, that is to say between twenty and fifty basis points.

There will be also a competition for benchmark status, because it is a key driver of the lowest-cost financing in a liquid market. A number of factors will influence the judgment of the market: transparency and liquidity of the market for repurchase agreement, existence of an efficient strip market ${ }^{13}$ which can be used to recalculate the exact value of each security on issue, predictable character of auction schedule, critical mass of Euro-denominated papers.

- The corporate bond market which is small, except in the UK, is expected to quickly develop its size, if one compares the European markets to the US, as Table 5 shows it.

But three conditions are necessary for such a development. First, the European institutional investor base has to be expanded. Mutual funds have been successful but the weak part played by the pension funds in continental Europe, except in the Netherlands, is certainly a handicap. Second, European firms need to show an increased desire to tap debt securities markets. They will be encouraged to do so by competition to improve their value-maximizing financial policies and by a larger basis to issue debt securities. But there is a third condition which is the removal of restricted regulations (tax policy, prudential asset rules).

13 It accounts why the Bundesbank, on June 13, 1996, announced plans to introduce the separation and separate trading of principal and interest for particular 10 and 30 year federal bonds during the course of 1997. Similar decisions were announced in 1997 in both Spain and the UK. In France, all OATS maturing on April 25 and October 25 (13 bonds in total) have been stripped since 1991. 
Table 5: Funds Raised in Capital Markets by Non financial Enterprises in Selected Industrial Countries, 1990-95

(in percent of total)

\begin{tabular}{|l|c|c|c|c|}
\hline & Bonds & Shares & Others & Total \\
\hline European Union & & & & \\
Countries & & & 75.13 & 100.00 \\
- Italy & $-0,68$ & 25.55 & 56.65 & 100.00 \\
- Netherlands & 1.17 & 42.19 & 69.02 & 100.00 \\
- Spain & 1.71 & 29.27 & 67.15 & 100.00 \\
- Sweden & $-0,88$ & 33.73 & & \\
\hline Canada & 7.14 & 27.91 & 69.95 & 100.00 \\
United States & 50.94 & 13.22 & 35.84 & 100.00 \\
\hline Japan & 5.48 & 11.38 & 83.14 & 100.00 \\
\hline
\end{tabular}

Source: IMF

\section{B. The equity market}

The Euro will be an additional incentive in the modernisation of European equity markets. Competition will continue to be fierce among the European exchanges. The rebalancing of turnover between London on the one hand and the partnership between Frankfurt, Paris and Zurich on the other hand has already emerged into a single electronic exchange. There will be a strong incentive for cross-border equity trading. The creation of paneuropean stocks indexes, defined in conjunction with D.W. Jones, has strengthened the credibility of the alliance between SBF-Matif, Deutsche Börse - DTB and Soffe, otherwise attested by the fist rank won recently got by Frankfurt on the 10 years Bund forward contract.

A recent report produced by a panel of French issuers under the umbrella of the "Paris Europlace" Association has made recommendations with the view of developing the Paris Stock Exchange, which will cover the development of popular shareholding, the pension funds and the strengthening of an independant capacity of financial analysis in France.

\section{The derivatives market}

The most direct impact of EMU on the structure of derivative contracts will be the elimination of currency derivatives between the currencies of the participating Member States. The market for interest rate swaps will become larger and more liquid and will certainly stretch outside the banking sector. The demand on interest rate spreads will apply for sovereign debt as well as private debt securities. The investors will look for hedging credit risk spreads between high-yield bonds and the Euro benchmark. 
All these elements represent a major revolution for the asset management policy of the insurance industry.

As the insurance industry assessed it, the potential benefits of establishing a Euro presence on international markets will be considerable in terms of market liquidity and depth, and lower funding costs for sovereign and private borrowers. Once the Euro is introduced, borrowers and lenders will begin to seek lower costs and higher returns across national boundaries. European financial markets could become less segmented, and there could be more uniformity in market practices and more transparency in pricing.

In the same way as the changeover to the Euro will have to be combined for all the information systems with the Millenium issue, in the same way the switchover of the financial sphere to the Euro will bring about a comprehensive transformation of asset management practices of the insurance industry.

The basic regulatory principles governing investments of insurance companies today are well known. They can be summarized as follows:

- list of regulated investments consisting of bonds, equities, real estate, loans and deposits. Authorised investments appear on a restricted list.

- asset allocation: standard distribution by type of asset, with a maximum of $65 \%$ in equities, $40 \%$ in real estate and $10 \%$ in loans.

- diversification: insurance companies are required to spread the risk attached to their investments, ie. no more than $5 \%$ in quoted shares of a single currency and $0.5 \%$ in an unquoted company.

- "congruence" or matching rules: liabilities in one currency must be covered by assets in the same one.

- localisation of the assets.

Therefore, the investment structure of insurers is strongly linked to their regulatory environment and the conditions of the market.

For instance, in France, the overall investment composition of French life insurance companies is dominated by bond investment ( $73.6 \%$ including commercial paper) which is due mainly to three factors: an average duration of liabilities similar to the average term of bonds (from seven to eight years); the result of historical high yields and regular income provided by bonds; and the high liquidity of the French government bond market. French Property/Casualty companies are more invested in stocks than Life companies. The investment policy of property/casualty insurers consists primarily of managing cash flow between the premium income and claims payments. They traditionally rely more on their realized capital gains than life insurers and are, therefore, strongly exposed to the currency risks.

The EMU will reduce transaction costs on European markets, that is likely to make the cross-border transactions easier. It will also remove currency risk which will reduce the volatility of the consolidated accounts of the companies (see table 6). 
Table 6: Currency loss/gain for French Insurance based on premium Income of French direct Insurer's subsidiaries in the European Union

\begin{tabular}{|l|c|c|c|}
\hline & 1994 & 1995 & 1996 \\
\hline $\begin{array}{l}\text { Currency loss/gain } \\
\text { (in million FFr) }\end{array}$ & $-1,221$ & $-6,089$ & $+7,413$ \\
\hline $\begin{array}{l}\text { As a of French } \\
\text { companies premium } \\
\text { income in the EU }\end{array}$ & $0.89 \%$ & $4.25 \%$ & $5.8 \%$ \\
\hline
\end{tabular}

\section{Source: FFSA}

The assets quality rule (investments issued in all OECD Member Countries), asset allocation rule and asset diversification rule should not experience major changes, provided that the solvency margin rules are not reviewed ${ }^{14}$. These changes will be to the benefit of insurers allowing them to reach for the most efficient allocation of their assets in a broader financial market.

As illustrated in chart 2, insurance companies are the second largest group of financial institutions in Europe after banks, but before mutual funds, pension funds and other institutions.

Figure 2: Investment Management in Europe

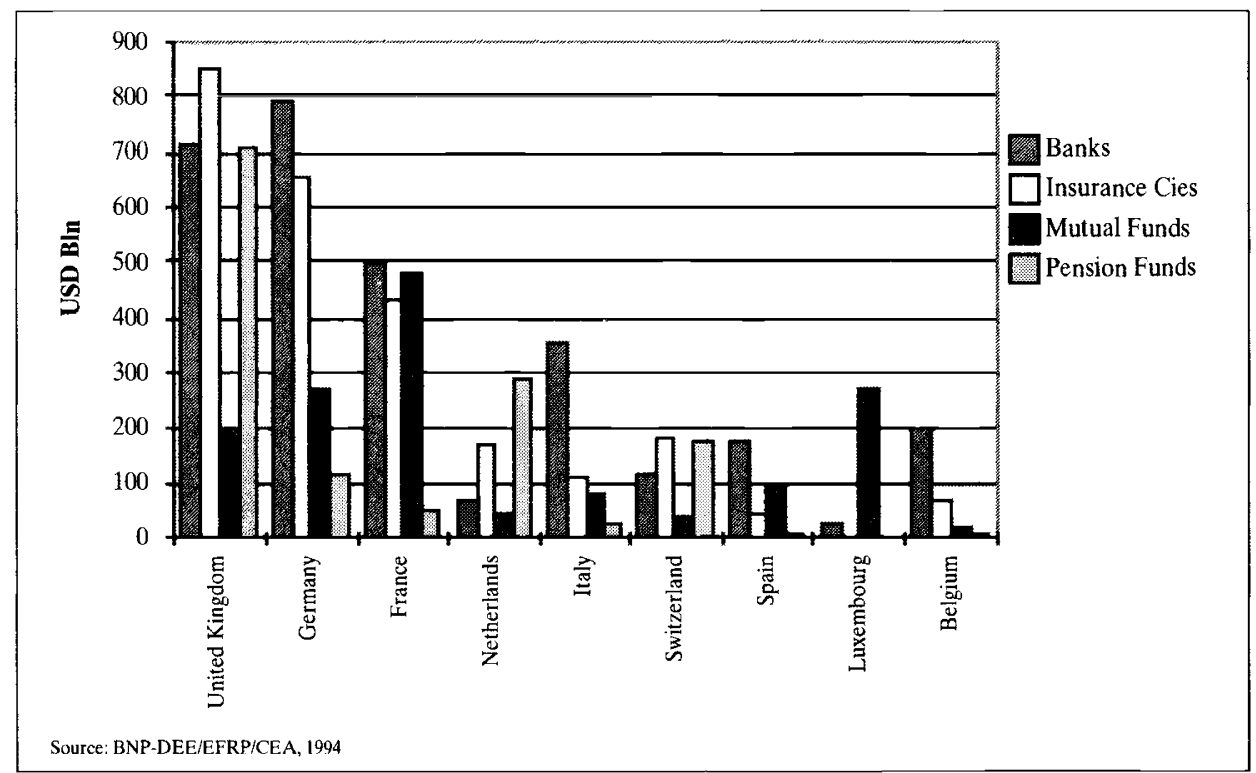

${ }^{14}$ In this article, we don'nt have room for making developments on this issue which is under discussion among the European regulators, the European Commission and the European industry. 
This classification is based upon a list of nine countries which represent the more important markets. In the insurance sector, the European market is dominated by three countries: the United Kingdom, Germany and France, which represent $74 \%$ of total insurers' investments in the EU, as shown in chart 3.

Figure 3: Total investments in Major European Insurance Markets

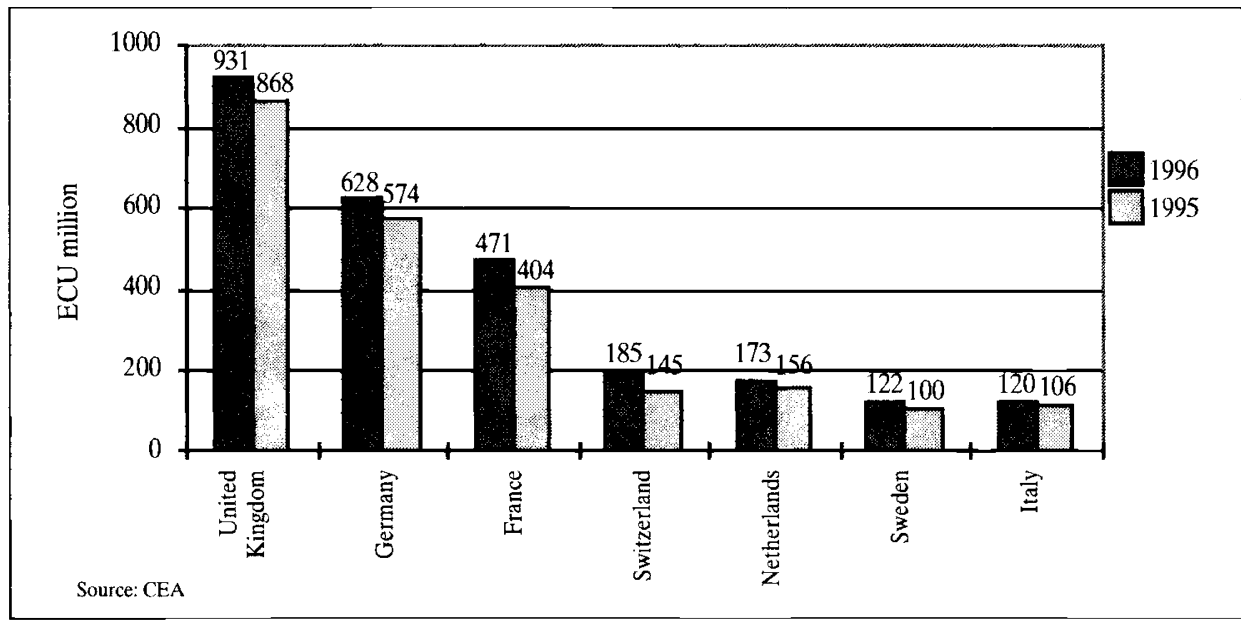

Furthermore, European insurance markets present different investment structures, and the impact of the EMU, will differ depending on the economic characteristics of the country.

Figure 4: Breakdown of total investments in major European insurance markets in 1996

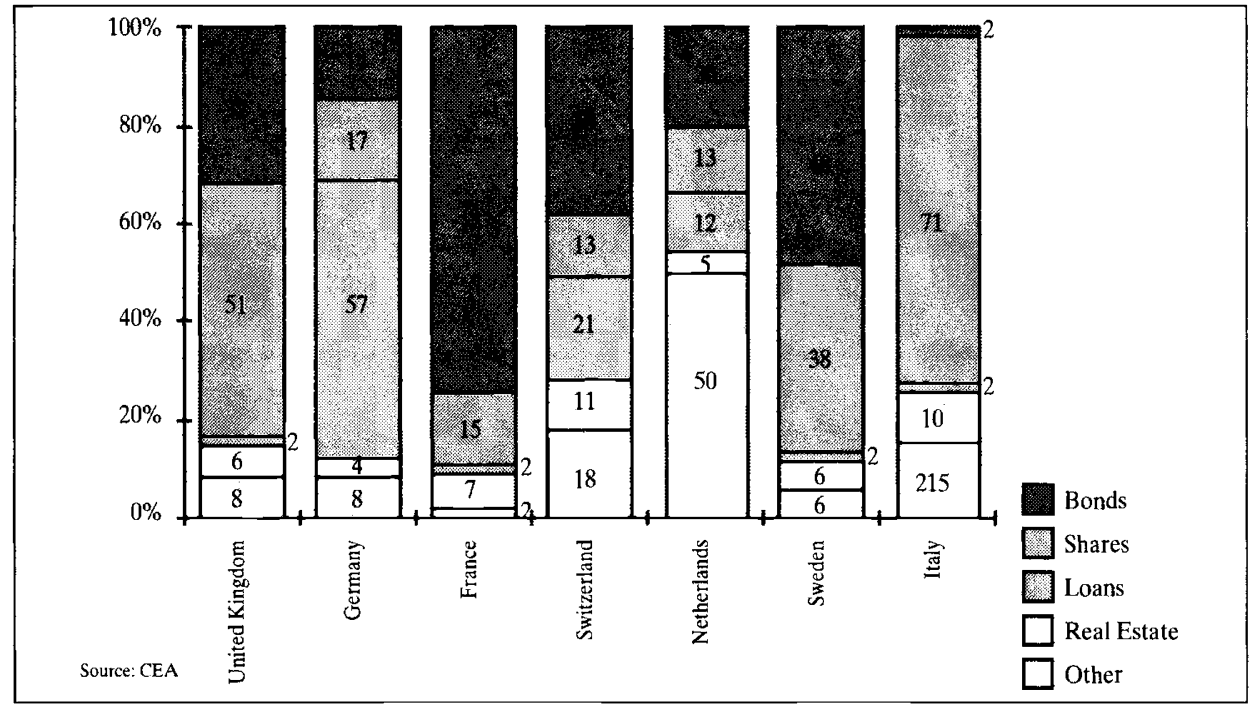


One can observe the importance of bond investment in France, stock investment in the UK, due to the high liquidity of the London stock market and loan investments in Germany due to the financing structure of the economy.

The Euro will not erase these differences which result from historical, cultural, taxation and commercial factors. For instance in France, the massive investment of life companies in bonds is due to the obligation of producing a surrender value to the policyholder, and to tax and accounting distortions detrimental to stocks. In the United Kingdom, a very important share of households savings is invested in stocks through pension funds. In Germany, the system of book reserves for the financing of occupational pension schemes has compensated the effects of investment strategy of the insurance companies, as it emerges from table 7.

Table 7: The holding of domestic listed stocks

\begin{tabular}{|c|c|c|c|c|c|}
\hline & & France & UK & US & Germany \\
\hline & GDP & $\begin{array}{l}1.548 \\
587\end{array}$ & $\begin{array}{l}1.135 \\
1643\end{array}$ & $\begin{array}{l}7.263 \\
8452\end{array}$ & $\begin{array}{l}2.361 \\
665\end{array}$ \\
\hline Individuals & Bn\$ & 135 & 345 & 3.800 & 100 \\
\hline & $\%$ capi & $23 \%$ & $21 \% *$ & $45 \%$ & $15 \%$ \\
\hline & $\%$ GDP & $9 \%$ & $30 \%$ & $52 \%$ & $4 \%$ \\
\hline Pension Funds & $\mathrm{Bn} \$$ & $3^{* *}$ & 446 & 1950 & $8^{* *}$ \\
\hline & $\%$ capi & $1 \%$ & $27 \%$ & $23 \%$ & $1 \%$ \\
\hline & $\%$ GDP & $0,2 \%$ & $39 \%$ & $27 \%$ & $0,3 \%$ \\
\hline Other domestic & $\mathrm{Bn} \$$ & 158 & 181 & 2.028 & 200 \\
\hline $\begin{array}{l}\text { institutional } \\
\text { investors }\end{array}$ & $\%$ capi & $27 \%$ & $11 \%$ & $24 \%$ & $30 \%$ \\
\hline & $\%$ GDP & $10 \%$ & $16 \%$ & $28 \%$ & $8 \%$ \\
\hline TOTAL & $\%$ capi & $51 \%$ & $59 \%$ & $92 \%$ & $46 \%$ \\
\hline & $\%$ GDP & $19 \%$ & $86 \%$ & $107 \%$ & $13 \%$ \\
\hline
\end{tabular}

Sources: OECD - Bank of England - Bundesbank - Banque de France, quoted in a recent report published by Paris Europlace on the expectations of the issuers

* A very important portion of the individuals saving in the U.K. is invested in stocks through pension funds

** For France and Germany, these funds are assets managed by pay-as-go system invested in stocks. But it does not include in Germany book reserves which represent \$ bn 172 at end 1996 (26\% of stock exchange capitalisation, $7 \%$ GDP).

The recent changes in the tax treatment of life insurance contracts in the Finance Law in France have enhanced the political intent of the Government to encourage investments in stocks. The legislator had the same concern when they were introduced in the so called "Thomas law", which created Pension Funds in France, a limit of $65 \%$ in bonds and a 
raising of the limit for non listed stocks to $10 \%$. This law will not be enforced, since the socialist government has decided to re-examine the issue.

The most important change in the investment strategy of the European insurance industry will come from the removal of the matching rules for Euro-denominated stocks and bonds on January 1, 1999. The question is already raised to remove any matching rule requirement even for the non-participating Member States to the Euro. The European Federation for Retirement Provision has also raised the issue in the debate about the Green Paper on supplementary pension schemes issued by the European Commission with the argument of a necessary portfolio diversification according to the prudent manner principle. It is hard to deny the existence of an exchange risk in those cases, but the competition between the insurance industry and the pension funds on the future European supplementary pension schemes market may create conditions of deregulation in asset management.

The management of bonds portfolios will focus on the spread analysis. Credit risk will play a greater role in the valuation of securities, and the development of a high-yield market in Europe is very likely. As Mary Pieterse-Bloen, who wrote the chapter on bond markets in an excellent book edited by Paul Temperton ${ }^{15}$ said it, in this more creditdominated environment the "winners" will be those with a fundamental understanding of credit risk. Insurance companies will have to make use of analysis and management control instruments of the risk evolution. For the listed companies which are rated by the rating agencies, it will become a crucial instrument of management to limit the downgrading of their assets portfolio by the rating agencies with the underlying consequences in terms of rating and of access to the capital markets. One may recall in this regard that Standard and Poor's makes a detailed examination of required capital for investment risk to assess default, volatility and concentration risks. The same method applies for reinsurance programmes of the insurance company.

We share the view that debt of different sovereign borrowers should still be thought of as making up individual yield curves. The default risk will have to be assessed in reference with a benchmark which may be either the Euro swap curve or one of the most attractive underlying assets. The first option might be favored by the London market, since it creates an advantage for the LIFFE. The second option should be favored by France and Germany, but the advantages of the German Bund are not decisive in terms of efficiency, liquidity and value-added services, in comparaison with French OAT.

It explains why the FFSA in its handbook on the Euro expressed the wish to create a european 10 years bond index from daily quotations by selected primary dealers. As a first step, the CNO-TEC ${ }^{16}$ method should, in this context, be preferred to the TME to determine the price of a life contract and the maximum interest rate allowed to calculate mathematical reserves. And an harmonisation of a long term index should be looked for between France, Germany and the Netherlands at least.

15 Chapter 15 - Book published by John Wiley and Sons.

16 TEC 10 is a floating-rate OAT. The TEC - Taux d'échéance constante - (constant date of payment rate) is produced by the french Committee for Bond Standardization, after an actuarial method, for each maturity from 1 to 30 years. It will quoted for each maturity every day by a selection of primary dealers. The TME is the classical 10 year Bond rate which is commonly used in life contracts. 
As for the equity market, it is hard to assess the listed companies which will capture a competitive advantage with the introduction of the Euro. It is fair to say that the culture of cost management that steady Deutschemark appreciation has inculcated in industry is likely to give Germany-based companies a competitive advantage. In this regard, the gains of productivity attained within the last five years by the German industrial fabric as well as by the German financial industry, including through restructuring operations, is very impressive. The advent of the Euro is likely to be equivalent to living in a hard currency environment for most European companies, and it will start immediately after the decision taken by the Finance Ministers to set up irrevocably the bilateral exchange rates of participating Member States currencies, that is to say as early as on May 3, 1998, regardless of whether the Euro will become a strong currency relative to the US dollar or the Japanese Yen.

In that context, the work of the asset managers in the insurance companies will be to compare performances of listed companies, sector by sector, all over Europe in a much more sophisticated manner than in the past. The Blue Chip stocks will probably be more expansive, attracting more investors, and other stocks may become cheaper than what they are today, and some may even disappear from the market. The number of issues in European stock market is currently high compared to the US, and eviction phenomenons may be expected.

Table 8: International Financial Markets 1996 (in billions of U.S. dollars)

\begin{tabular}{|l|c|c|}
\hline & Stock Capitalization & Bond Market Value \\
\hline Paris & 586 & 1259 \\
\hline Frankfurt & 665 & 1868 \\
\hline EU 8 countries* & 1870 & 4076 \\
\hline EU 13 countries** & 2672 & 6703 \\
\hline United States*** & 6842 & 11091 \\
\hline Tokyo & 3011 & 4905 \\
\hline London & 1711 & 629 \\
\hline
\end{tabular}

Source: FIBV

* 8 countries: Germany, Austria, Belgium, Finland, France, Netherlands, Ireland, Luxembourg.

** 13 countries: 8 EU countries plus Italy, Spain, Sweden, Denmark, Portugal.

*** NYSE stock capitalization.

Diversification outside the Euro area will therefore become crucial to achieve higher yields, but investors will be confronted with the problem of matching rules.

To meet all these challenges, the insurance companies need to reflect upon their own financial strategy and to reconsider their organization. Additional competences will be necessary to analyse new kinds of issuers, to make a clear assessment of the credit risk, to develop an appropriate use of derivatives. Either they will have the in-house resources in the company or within the group to conduct an efficient investment policy on the Euro capital markets or they will benefit from external support. 
Other issues have to be examined in this context. Two of these seem to be of great importance: the asset management and the use of derivatives.

There is a certain logic to liberalize the prudential rules on the asset management as a consequence of the unification of the Euro capital markets. But in the mean-time a keen attention has to be paid to the capacity of institutional investors to meet their commitments. It explains why the insurance industry is anxious to get the application of solvency margin principles be recognized for the management of occupational pension schemes to cover the financial risks linked to the operations on the capital markets and to meet the long term commitments vis-à-vis the pensioners. Otherwise there will not be a level playing field between the pension funds and the insurance companies on the promising market of supplementary pension schemes.

The European regulators are also quite aware of increased failure risks on a deregulated marketplace. It explains why the discussions on the draft directive on liquidation of insurance companies are reopened, why the European Commission is anxious to complete the negotiations on insurance groups directive and why the review ol solvency margin rules applied to individual insurance companies takes into consideration the perspective of a Euro capital market. It is not surprising in the meantime to see the sudden speeding up of reflections on the supervision of financial conglomerates.

In this context, the rules of the game have also to be clarified as for the use of derivatives by insurance companies. The starting point is that derivatives can contribute to the liquidity of assets portfolios and allow "customized "management strategies. They help also manage the interest rate risk related to the investment of future insurance flows such as premium invested in reserves. They contribute to optimizing the return on portfolios and reduce the transaction costs.

In the US, derivatives have long found favor as a means of financial risk management. The European markets have been slower to adopt them. In France, their development has been delayed by the lack of appropriate prudential, tax and accounting rules.

The third Community directives have allowed the use of derivatives, but the regulatory framework for derivatives comes under the competence of the Member States themselves. In the U.K., the 1994 regulations introduced the concept of "sound and prudent "management of an insurance company and placed obligations on directors in this respect. To clarify the scope of the concept, the DTI issued guidance notes. Both the directors of the company and the appointed actuary are subject to guidance on monitoring the actions of the investment managers in the use of derivatives. Insurance companies cannot be active traders of derivatives, since speculation would be inconsistent with the reduction in Risk test. But the bigger danger is that the insurance company may be only an occasional user of derivatives leading to a shortage of suitably skilled and experienced staff. These two systems of control required (control by directors, role of the actuary) provide accurate and up to date measurement of asset exposure and counterparty risk, but also capacity of assessing the level of matching between property-limited assets and liabilities. There are a number of tests that must be passed to prove the assets are admissible. The directors have also to publish a statement in the DTI returns describing the use of derivatives. 
In France, the regulatory framework lags far behind that of the other Member States. Discussions are under progress among the Treasury and the industry. A number of issues are still pending, notably the definition of liquid assets held or earned within forward purchase transactions, the prohibition of speculative operations, the limits of compensation for transactions by mutual agreement, the asset-liability adequacy and the accounting and taxation aspects.

With the changeover to the Euro, it is certainly a revolution which is under way in the asset management field. Risks and opportunities will have to be properly assessed by every insurance company, with the view to searching for ideal strategy. Beneficial aspects of the Euro will occur on the investment side but also on the underwriting side, both for customers and shareholders.

\section{The Single Market and the Euro}

A great deal of work has been done in most of the Member States of the European Union in the changeover to the Euro. Very few studies have focused on the post-Euro insurance market. In this regard, a tribute must be paid to the recent study conducted by Data Monitor which has examined in a systematic way the implications of a single European currency on the insurance industry by considering the key drivers affecting the insurance markets.

\subsection{A rapidly changing industry}

The changeover to the Euro is taking place in the context of a rapidly changing industry. There is an increasing consolidation through mergers and acquisitions. The wave continued to swell in 1997 on American and European markets as well. In the U.S., overcapitalization fueled the fever, as insurers looked for ways to deploy excess capital toward limited growth opportunities. In the life Health Financial Services transactions, a total of \$ 86 billion in merger and acquisition activity was reported as of December 1997, bringing the number of transactions from 45 in 1995 to 95 in 199717 . The flurry of M \& A activity has led the mutual insurers to react through the creation of Mutual holding company structures. Current market imperatives may help explain why in tangible assets (brands, goodwill, people) have driven valuations in $\mathrm{M} \& \mathrm{~A}$ to unprecedent highs. In Europe, after the successful mergers between AXA and UAP and between Sun Alliance and Royal, Credit Suisse acquired Winterthur group in a $\$ 9$ billion stock swap in August. Zurich group and B.A.T. Industries plc agreed in October 1997 to merge their financial services and insurance operations. Acquisitions of Scudder, Stevens and Clark by Zurich group and of Furman Selz - brokerage firm by ING Group could be also mentioned.

The movement of consolidation involves reinsurance industry and broker firms as well (Munich Re and American Re; March \& Mac Lennan and Johnson \& Higgins; Aon and Alexander \& Alexander).

Consolidation has the effect of producing larger groups, notably in the commercial lines of business and accordingly to facilitate alternative forms of risk transfer, such as

${ }^{17}$ Source: Best's Review - Life/Health Edition January 1998. 
captive insurance, finite-risk insurance where funds are transferred to a subsidiary to set aside reserves for expected future losses and capital markets risk transfer (Cat Bonds). Many reinsurers have embraced the alternative market by establishing subsidiaries, affiliates or divisions dedicated to single-parent captives and risk retention groups.

Consolidation reflects the recognition of fundamental changes in the needs of the policy-holders and the nature of the insurance business. Clients are more international-or worldwide - oriented, more sophisticated also, more demanding in the quality of services, and more interested than in the past to consultative or cooperative relationships.

Consolidation reflects also the need to spread information technology investments over a broader base. Three factors interfere in this regard: first the total cost of EMU compliance which has been estimated for the french market to $0.5 \%$ of total premium income underwritten and which mainly consists of information technology investments (62\% according to Data Monitor industry interviews); second, the year 2000 glitches which have two dimensions, one related to potential contentious issues with the insureds and the other to risk missing the deadline in the adaptation of internal computers.

A number of other developments have contributed to promote merger and acquisition activity. Among them, we can mention the high level of competition reducing premiums, market fragmentation with new distribution channels, pressure from investors looking for higher return on equity, adoption of risk-based capital analysis, spread of risks between "soft market" and "hard market", increased use of technologies cutting costs and enhancing services, consolidation in other industries reducing the number of buyers.

In the commercial lines, major corporations are being forced to expand operations internationally. They are expecting from the insurance providers new qualities in terms of expertise in underwriting, long term solvency, specialised technical support and advanced information technology, administrative cost efficiency, and global quality of services worldwide. It explains why the number of active underwriters has been concentrating dramatically since the beginning of the nineties. It becomes absolutely crucial to identify the best corporate strategy and to move toward central coordination generating cost savings.

Across Europe, cost savings in insurance expenditure are one of the most compelling arguments for establishing a captive, and at the same time to avoid setting up one. The development of captives across Europe, as it is illustrated by chart 5, is the result of opportunities in tax havens and perception by the client of an inadequate insurance rating, compared to loss history.

The answer of commercial insurers is to try and maintain close relationships with corporations, provide tailor-made services and offer competitive pricing. The falling-down of rates in the last two years is a clear evidence of the responsiveness of the market in an environment of low level of losses and over capacity. It will lead sooner or later to a blunt adjustment of the rates, to a withdrawal of less competitive companies from the market and to a search for innovation. The supply of pan-European products denominated in Euro might be a good answer for companies which do not require tailor-made intervention.

Consolidation in the direct insurance sector will influence the reinsurance market. The market trends imply a reduction of premium ceded, the development of alternative 
Figure 5: Development of captives in Europe

Captive insurance as a \% of commercial insurance premium, 2000.

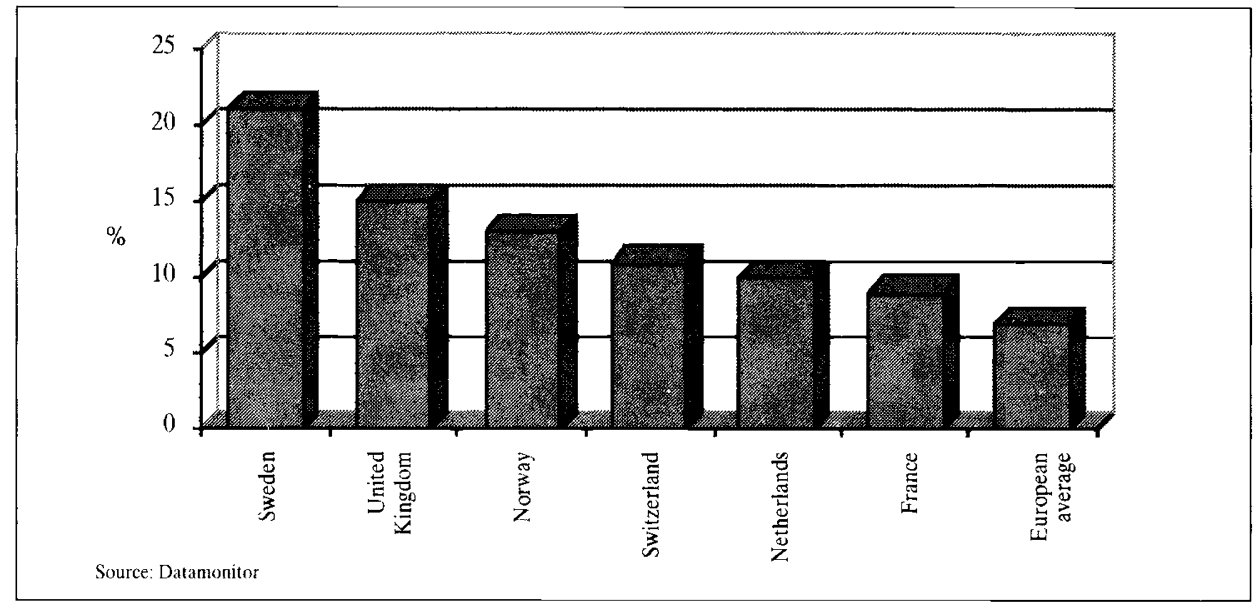

Figure 6: Worldwide growth of proportional/non-proportional business, 1991-1996.

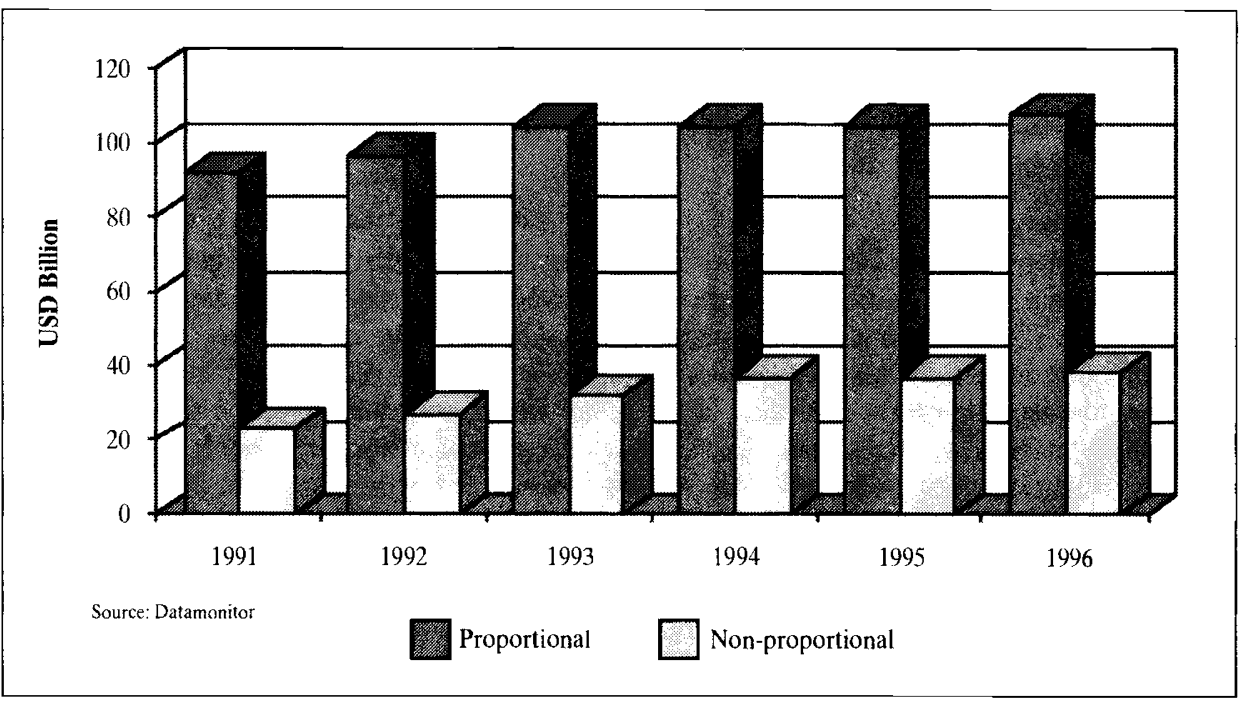

risk transfer and an increase in non proportional reinsurance treaties, as it appears in chart 6 below.

General insurance is confronted in Europe to a movement of deregulation linked to the "acquis communautaire "more than to a new environment with the advent of the Euro. Markets will remain national-based. Competition among the various channels of distribution will increase. So it will be crucial for the insurance companies to improve their 
operating income through a more efficient segmentation approach and a reduction of charges (commissions and overheads).

In the personal lines, the thread is not the advent of the Euro, even if it will encourage more efficient asset management strategies but the crisis of the Welfare State and the impending "Papy Boom". The Green Paper on supplementary pension schemes is an introduction to the debate which must take place at the Community level. European Insurance companies through the CEA have expressed a strong feeling that they have the vocation to operate on the market through a level playing field with other actors such as the pension funds. The conclusions that the European Commission will draw from the debate are still unclear. But it seems hard to imagine that the solution proposed be the strict application of the Treaty with the view to getting a complete freedom of capital movements and a freedom of services.

It would be quite strange to impose no solvency requirements to meet very long term commitments vis-à-vis the pensioners and to maintain or ever increase the level of solvency requirements for life contracts the duration of which is around 8 years.

\subsection{Toward a financial services and capital market integration?}

The introduction of the Euro should, of itself, hasten a qualitative increase in the integration of wholesale markets, so there will be a pressure to remove all remaining restrictions on investment: currency matching rule of course but also more subdued investment restrictions. Pension funds are the most proactive proponents of a comprehensive asset management liberalization. Insurance companies have no objection to go along such an evolution provided that the management of pension rights be guaranteed in satisfactory conditions.

Some interesting ideas have started to float in the ECOFIN to address the injustified fragmentation of the market for individual and collective portfolio management through an amendment to the Investment Services Directive. But some other may be carefully examined. The European Commission, notably the DG XV, develops more and more frequently the idea that the split between home/host country responsibilities will need to be reconsidered in the light of EMU, in a number of areas which condition the right to do business in financial services, including insurance, on a cross-border basis. It explains why the Commission spent a lot of time to prepare an interpretative communication on General Good in insurance. In asserting that compulsory measures such as Bonus-Malus provisions, surrender value, maximum guaranteed interest rates impede the full application of the home country control and in recalling the jurisprudence of the Court of Justice regarding the fact that general good has not to apply harmonized matters, the Commission tries and puts into question consumer protection measures imposed by the host country are likely to impede the freedom of services.

The alternative solution is to better harmonize the national provisions regarding the consumer protection.

But the main problem in the Euro area will be the tax distortions. Thanks to the adoption of a code of conduct by the ECOFIN Council in december 1997, it may become possible to combat the measures which impede the efficient functioning of the single 
market. The draft directive on saving taxation is also an instrument to avoid unfair attitudes from certain Member States.

From this movement toward capital market integration may emerge different kinds of operators, the global players which will have the critical mass in the asset management and which will operate on every market of the European Union, the operators which will have a niche approach and the rest which will be regional or local players. It is hard to say who will be the winners.

But consolidation will likely continue until investor returns recover to the level of broader investment returns. In this context, it will be crucial for every insurance company to get a clear view of its own strategy, to focus on increased investment in human capital and to maintain a control on efficient distribution networks.

The changeover to the Euro is certainly the most important act since the signature of the Rome Treaty. Insurance industry has key cards in its hands. It is up to every company to adapt its strategy to the asset management revolution, to the new conditions of the market. It is the responsibility of the European industry to promote its image of efficiency, innovation and market conduct respect. It is up to national governments to make sure that a high degree of consumer protection be maintained, that systemic risks are efficiently controlled. It is up to consumers, households as well as companies or non wage earners to make sure that they will get the fair price and the most qualified service.

Euro is the new frontier of insurance. It has the power to shift completely the rules of the game. Therefore, insurance companies have to comply with and apply the precaution principle. 